\title{
薬凨師と医師の連携による 慢性腎臓病患者の薬郕管理
}

\section{要 旨}

診断し, 処方箋を書く医師は, 薬物動態・相互作用について必ずしも得 意なわけではない. それを補うためには, これからの薬剤師は「調剤し服 平田純生 薬指導をする人」から「薬物適正使用を推進する人」に変わっていく必要 がある.それによって, (1)腎機能低下患者の中毒性副作用の未然防止, (2) 適切な服薬指導による腎機能悪化・心血管合併症の防止, (3)腎毒性薬物に よる薬剤性腎障害の防止について, 医師との緊密な協力によって成し遂げ なければならない.

〔日内会誌 $107 ： 826 〜 833 ， 2018 〕$

Key words 慢性腎臓病，薬物適正使用，薬物動態，相互作用，薬剤性腎障害

\section{はじめに}

腎機能が低下した患者に腎排泄型の薬剤を投 与することで, さまざまな有害事象が発生す る、神経障害性疼痛治療薬のプレガバリン（リ リカ $\left.{ }^{\circledR}\right)$ による耐え難いめまいや意識消失, 同 じく腎排泄型の抗不整脈薬のピルシカイニド (サンリズム $\left.{ }^{\circledR}\right)$ による意識消失, シベンゾリン (シベノール ${ }^{\circledR}$ ) による低血糖が腎機能低下症例 で起こりやすいことはよく知られている。抗へ ルペスウイルス薬のアシクロビル（ゾビラック ス $\left.{ }^{\circledR}\right)$ やバラシクロビル (バルトレックス $\left.{ }^{\circledR}\right)$ に よる呂律困難を伴う意識障害や, 溶解度が低い ために遠位尿細管や集合管で結晶を生じること によって起こる腎後性腎障害は皮膚科から, 非ステロイド性抗炎症薬（non-steroidal anti- inflammatory drugs：NSAIDs）の漫然投与によ る腎障害や, 活性型ビタミン $\mathrm{D}_{3}$ 誘導体製剤のエ ルデカルシトール (エディロール $\left.{ }^{\circledR}\right)$ とCa製剤 の併用による高カルシウム血症から起こる薬剤 性腎障害（drug-induced kidney injury：DKI）は 整形外科からの処方で多発している。これらの 診療科はあまり採血をしないため, 腎機能が不 明なまま, 腎排泄性薬物やDKI起因薬物を投与 されることがある.このような中毒性副作用に は, 薬剤師が十分な注意を払って処方監査し, 用量を適正化したうえで, 副作用の初期症状へ の対応を患者に服薬指導することで防げるもの もある。 


\section{1. 薬物動態・薬物相互作用に強い薬剤師}

1 例を挙げてみる，例えば，ネフローゼ症候 群では血中LDL-C (low density lipoprotein-cholesterol）值が上昇しやすくなるため，しばしば スタチン系薬剤が併用される。シンバスタチン (リポバス ${ }^{\circledR}$ ) のバイオアベイラビリティ（非静 注製剂が静脈内に入る割合で, 吸収率と初回通 過効果によって規定される）は５\%以下である が，グレープフルーツジュースを一緒に飲むこ とで，活性体のシンバスタチン酸のAUC（area under curve）が7倍にもなる1).これにより， 筋肉痛, 横紋筋融解症のリスクが極めて高く なってしまう.しかも,グレープフルーツジュー スは小腸の代謝酵素CYP3A4 を不可逆的に阻害 するため，朝にグレープフルーツを摂取し，夕 食後にシンバスタチンを服用しても相互作用は 起こり得る.

ネフローゼを起こしやすい膜性腎症等では, 脂質異常症を伴いやすいため，スタチン薬が高 頻度で投与されるが，ステロイド抵抗性である ことが多く, ステロイドが無効の場合には免疫 抑制薬としてシクロスポリンが併用されること がある. シクロスポリンとストロングスタチン であるピタバスタチン (リバロ $\left.{ }^{\circledR}\right)$, ロスバスタ チン（クレストール ${ }^{\circledR}$ ) は併用禁忌となってい る. 添付文書上では「ピタバスタチン・ロスバ スタチンの血漿中濃度が上昇し, 副作用の発現 頻度が増加するおそれがある。また，横紋筋融 解症等の重篤な副作用が発現するおそれがあ る」と記載されているが, この相互作用はフル バスタチン（ローコール ${ }^{\circledR}$ ) 以外の全てのスタ チンで起こり，そのメカニズムは有機アニオン トランスポータであるOATP1B1 (OATP-C/ OATP2）を介するスタチンの肝取り込みをシク ロスポリンが阻害するためといわれている22.

つまり, シクロスポリンを服用している患者は スタチンが肝で取り込まれない, つまり, 肝代 謝されないため, 筋毒性の強いスタチンによる
横紋筋融解症が発症する可能性がある.ピタバ スタチン・ロスバスタチンのみがシクロスポリ ンと併用禁忌になっているため, 仕方なくアト ルバスタチン (リピトール $\left.{ }^{\circledR}\right)$ をスタチンと併 用する医師が多いが，これによって，多くの患 者が筋肉痛を発症している。これに気付かずに 放置して横紋筋融解症になれば，筋肉が崩壊し てミオグロビンが血中に入り，尿細管が障害さ れて急性腎不全を引き起こす。今までは，この ようなケースは腎炎が急に増悪して腎不全を起 こしたと考えられていたが, 実は医原病のケー スが多いと思われる。薬物動態を知っている薬 凨師が適切な処方監査をすれば，このようなこ とから不幸にして透析導入となるような事態は 防げる可能性がある.

実は,アトルバスタチンはOATP (organic anion transporting polypeptide) 阻害に加えて肝 代謝酵素CYP3A4の基質であるため，シクロス ポリンによるCYP3A4の阻害作用もあるため か, 併用禁忌になっているピタバスタチン・ロ スバスタチンよりも相互作用が強い（表 1)2). これも薬物動態・相互作用の専門家である薬剤 師だからこそ防げる相互作用といえるかもしれ ない，今や，薬剤師は「調剤し服薬指導をする 人」から,「薬物適正使用を推進する人」に変わ りつつある。

\section{2. 病態を踏まえた服薬指導}

薬剤師には, この他にも, 薬物の適正使用に 地道に貢献する重要な仕事がある。慢性腎臓病 （chronic kidney disease：CKD）は早期発見し, 適切な処置を行えば治療が可能な疾患である. 例えば，腎機能はそれほど悪化していないもの の, タンパク尿が出ている状態（ステージ1〜 2：表2）では，糖尿病や高血圧，メタボリック シンドローム等のリスクファクターを有する症 例の腎機能が悪化する確率が極めて高いことが 知られている。 そのため, レニン・アンジオテ 
表 1 シクロスポリンとスタチン薬の相互作用

\begin{tabular}{|c|c|c|c|c|c|c|}
\hline $\begin{array}{l}\text { 成分名 } \\
\text { 商品名 }\end{array}$ & \begin{tabular}{|c|} 
プラバスタチン \\
メバロチン
\end{tabular} & \begin{tabular}{|c|} 
シンバスタチン \\
リポバス
\end{tabular} & $\begin{array}{c}\text { フルバスタチン } \\
\text { ローコール }\end{array}$ & \begin{tabular}{|c|} 
アトルバスタチン \\
リピトール
\end{tabular} & $\begin{array}{c}\text { ピタバスタチン } \\
\text { リバロ }\end{array}$ & $\begin{array}{l}\text { ロスバスタチン } \\
\text { クレストール }\end{array}$ \\
\hline 脂溶性 & + & ++++ & +++ & +++ & ++++ & ++ \\
\hline バイオアベイラビリティ & $18 \%$ & 5\% 以下 & $30 \%$ & $12 \%$ & $60 \%$ & $20 \%$ \\
\hline $\begin{array}{l}\text { 主な CYP 代謝酵素 } \\
\text { () は基質特異性が低い }\end{array}$ & $(3 \mathrm{~A} 4)$ & $3 \mathrm{~A} 4,2 \mathrm{C} 8$ & $2 C 9$ & $3 \mathrm{~A} 4,(2 \mathrm{C} 8)$ & $(2 C 9)$ & $2 C 9,(2 C 19)$ \\
\hline $\begin{array}{l}\text { グレープフルーツジュー } \\
\text { スによる血中濃度上昇 } \\
\text { (AUC) }\end{array}$ & - & $2-10$ & - & $1-4$ & - & - \\
\hline $\begin{array}{l}\text { シクロスポリン併用に } \\
\text { よる筋肉痛・横紋筋融 } \\
\text { 解症の発症 }\end{array}$ & Yes（数例） & Yes & No & Yes & Yes & Yes \\
\hline OATP1B1 の基質 & Yes & Yes or No & No** & Yes & Yes & Yes \\
\hline $\begin{array}{l}\text { シクロスポリン併用に } \\
\text { よる血中濃度上昇 } \\
(\mathrm{AUC}){ }^{*}\end{array}$ & $\begin{array}{l}5-10 \text { 倍 } \\
23 \text { 倍 } \\
5-12 \text { 倍 }\end{array}$ & $\begin{array}{c}6-8 \text { 倍 } \\
2.6 \sim 8.0 \text { 倍 } \\
3-8 \text { 倍 }\end{array}$ & $\begin{array}{c}\text { 2-4 倍 } \\
\text { データなし } \\
3 \text { 倍 }\end{array}$ & $\begin{array}{l}6-15 \text { 倍 } \\
7.5 \text { 倍 } \\
6-9 \text { 倍 }\end{array}$ & $\begin{array}{l}5 \text { 倍 } \\
4.5 \text { 倍 } \\
5 \text { 倍 }\end{array}$ & $\begin{array}{l}5-10 \text { 倍 } \\
3.8 \text { 倍 } \\
7 \text { 倍 }\end{array}$ \\
\hline $\begin{array}{l}\text { 腎機能低下患者への減 } \\
\text { 量の必要性 }\end{array}$ & 必要なし & 必要なし & 必要なし & 必要なし & 必要なし & 減量すべき \\
\hline
\end{tabular}

*上段は Neurvonen らの報告 a）より，中段は杉山らの報告 b）より，下段は平田らの報告 c）より引用

a) Neuvonen PJ, et al : Simvastatin but not pravastatin is very susceptible to interaction with the CYP3A4 inhibitor itraconazole. Clin Pharmacol Ther $63: 332-341,1998$.

b）杉山雄一，前田和哉：薬物トランスポーターの分子多様性，組織特異性，遺伝子多型. 日薬理誌 125：178-184, 2005.

c）平田睦子，他：シクロスポリンによるスタチン系薬剤の著しい血中濃度増加作用とその機序及び添付文書における情報の解析. Bull Natl Inst Health Sci 123 : 37-40, 2005.

**フルバスタチンが OATP1B1 の基質になるか否かについては統一された見解がないが，他のスタチン薬に比しフルバスタチンの 血中濃度上昇の影響が最も小さく，たとえ OATP1B1 の基質であったとしても，その基質親和性は低いと考えられている.

表 2 CKD の重症度分類 (CKD 診療ガイド 2012 より引用)

重症度は原疾患・GFR 区分・蛋白尿区分を合わせたステージにより評価する．CKD の重症度は死亡，末期腎不 全，心血管死亡発症のリスクを $\square$ のステージを基準に， する.

\begin{tabular}{|c|c|c|c|c|c|c|}
\hline \multicolumn{2}{|l|}{ 原疾患 } & \multicolumn{2}{|l|}{ 尿蛋白区分 } & A1 & $\mathrm{A} 2$ & A3 \\
\hline \multirow{2}{*}{\multicolumn{2}{|c|}{ 糖尿病 }} & \multirow{2}{*}{\multicolumn{2}{|c|}{$\begin{array}{l}\text { 尿アルブミン定量 }(\mathrm{mg} / \text { 日) }) \\
\text { 㽷アルブミン/Cr 比 }(\mathrm{mg} / \mathrm{gCr})\end{array}$}} & 正常 & 微量アルブミン尿 & 顕性アルブミン尿 \\
\hline & & & & 30 未満 & $30 \sim 299$ & 300 以上 \\
\hline \multirow{2}{*}{\multicolumn{2}{|c|}{$\begin{array}{l}\text { 高血圧，腎炎 } \\
\text { 多発性囊胞腎，移植腎 } \\
\text { 不明，その他 }\end{array}$}} & \multirow{2}{*}{\multicolumn{2}{|c|}{$\begin{array}{c}\text { 尿蛋白定量（g/日） } \\
\text { 尿蛋白 Cr 比（g/gCr） }\end{array}$}} & 正常 & 軽度蛋白尿 & 高度蛋白尿 \\
\hline & & & & 0.15 末満 & $0.15 \sim 0.49$ & 0.50 以上 \\
\hline \multirow{6}{*}{$\begin{array}{l}\text { GFR 区分 } \\
(\mathrm{mL} / \text { 分/1.73 m²) }\end{array}$} & G1 & 正常または高値 & $\geqq 90$ & & & \\
\hline & $\mathrm{G} 2$ & 正常または軽度低下 & $60 \sim 89$ & & & \\
\hline & G3a & 軽度～中等度低下 & $45 \sim 59$ & & & \\
\hline & G3b & 中等度～高度低下 & $30 \sim 44$ & & & \\
\hline & G4 & 高度低下 & $15 \sim 29$ & & & \\
\hline & G5 & 末期腎不全（ESKD） & $<15$ & & & \\
\hline
\end{tabular}

ンシン系 (renin-angiotensin system：RAS) 阻害 薬，つまりACE (angiotensin-converting enzyme) 阻害薬やARB (angiotensin type1 receptor blocker)
の投与を，血圧低下だけでなくタンパク尿抑制 のために開始する。それによって, CKDの進行 はかなり抑えられるが, この段階では, 患者に 


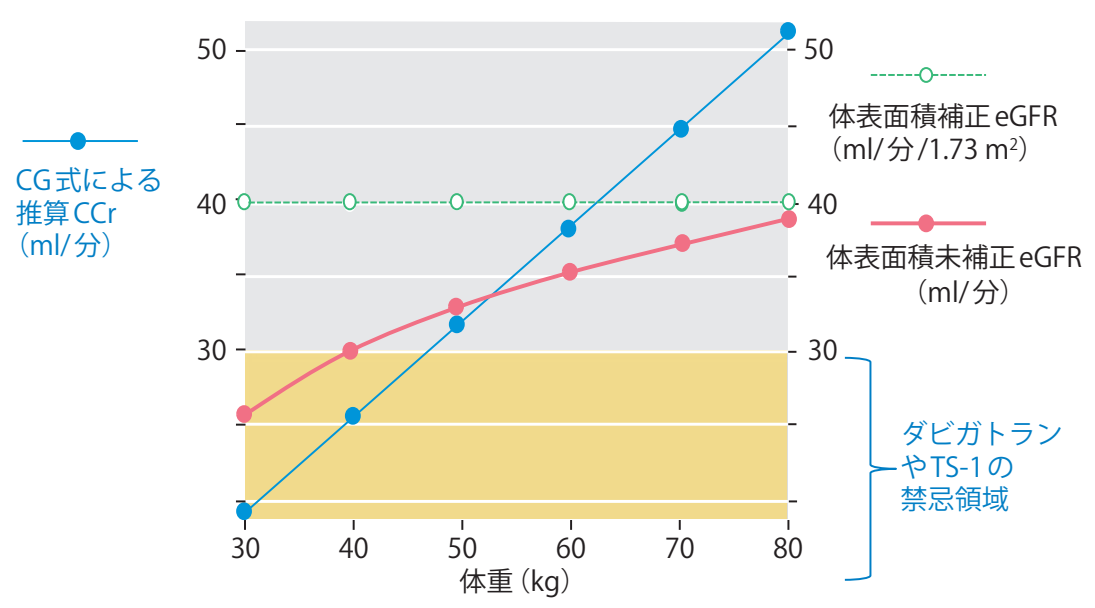

図 1 体重と eCCr, eGFR の関係

85 歳女性，血清 $\mathrm{Cr}$ 值 $1.0 \mathrm{mg} / \mathrm{dl}$ ，身長 $150 \mathrm{~cm}$ の場合

自覚症状はないため, 往々にして服薬アドヒア ランスが不良で, 再受診しないことが多い.

そこで, 薬剤師による服薬指導が不可欠に なってくる.「これは血圧を下げる薬と書かれて いますが，実はあなたの腎臓を守るとともに， 心臓を守る薬でもあります. CKDは, この薬を 飲まなければ, 心筋梗塞や脳卒中, 心不全等で 死亡するリスクが非常に高い病気です。早いう ちにCKDが見つかったのはむしろラッキーなこ となのですから, この薬をしっかり飲んでくだ さい，そして，毎月必ず受診してください。そ うすれば，腎蔵だけでなく，心蔵・血管も守る ことができます」一このように，「早く見つかっ て良かったですね」とポジティブに伝えること が肝心であり，それだけで，服薬アドヒアラン スの改善につながると思われる。また，ほとん どの患者は重症にならなければ症状が出ないた めか，病識を持っていない方が多いため, CKD がどのような病気なのかをしっかり伝えること も, 薬凨師の努めとして大切である. 医学部同 様, 薬学部も 6 年制となった今, 薬郕師は病態 に関する知識及び高いコミュニケーション能力 もしっかり身につけていく必要がある.

\section{3. 正確な腎機能の把握も大切}

添付文書に記載されている腎機能表記の多く がクレアチニンクリアランス (creatinine clearance : CCr) であり，その予測式としてCockcroft-Gault（CG）式の使用が推奨されている. ただし, CG式は体重が2倍になればCCrが2倍に 推算され，加齢とともに低下しやすい式である という特徴を知っておく必要がある（図1)。す なわち, 肥満患者では腎機能を過大評価してし まうという久点があるため, ハイリスク薬であ るダビガトラン (プラザキサ ${ }^{\circledR}$ ) やTS-1（ティー エスワン $\left.{ }^{\circledR}\right)$ の投与時には，このような腎機能 の見誤りが出血リスクや3), 骨髄抑制のリスク 増大につながることが想定される。

また, 抗がん薬で唯一, 腎機能に応じた推奨 投与量を計算できるCalvert式は以下のように 表される.

投与量 $(\mathrm{mg})=$ 設定AUC $(\mathrm{mg} / \mathrm{ml} /$ 分） [GFR $(\mathrm{ml} /$ 分 $)+25)]$

欧米では，この式のGFRにCCrを代入しても問 題なかった．なぜならば，血清Cr值が $0.2 \mathrm{mg} / \mathrm{dl}$ 高めに投与されるJaffe法によって測定していた ので, $\mathrm{CCr} \fallingdotseq \mathrm{GFR}$ とっていたためである. しか 
し, 我が国では, 正確に測定される酵素法によ るため, 腎機能が過大評価され, 投与量過多に なり, 血小板減少症等の副作用が多発している.

体表面積補正eGFR (ml/分/1.73 m²) はmg/ $\mathrm{kg}, \mathrm{mg} / \mathrm{m}^{2}$ 表記の薬物の投与設計には有用であ るが，標準体型男性以外では固定用量の薬物投 与設計には使えない。図1を見ると, 体表面積 補正eGFRには体格が全く考慮されていないこ とがわかる。ただし, 身長・体重から体表面積 を算出して補正を外したeGFR（ml/分）は血清 Cr值を基にした予測式のなかでは正確性が高い ものの, 瘦せた高齢者では過大評価しがちであ ることも理解しておくべきである. MRSA (methicillin-resistant staphylococcus aureus) 等 の院内感染では, 瘦せた長期臥床高齢者のよう な易感染患者がターゲットとなり, 血清Cr值が 低值の症例が多い. そのため, 腎排泄型抗菌薬 であるバンコマイシンの投与設計時には, 腎機 能の過大評価を避けるため, 血清Cr值をもとに した推算式を使用せず，実測CCrの測定あるい はシスタチンCをもとにしたeGFRの推算が推奨 される. 薬物投与設計には薬物の尿中排泄率と 正確な患者の腎機能が必要であり, 医師も薬剤 師も患者の体格・活動性を評価したうえで, 腎 機能を正しく評価する必要性がある.

\section{4. 薬剤性腎障害を防ぐ}

DKIが起こりやすい最大のリスクは, 既存の 腎機能低下または高齢者であり, 腎毒性のある 薬剤に関する医師への情報提供・提言も薬剤師 の重要な役割である，例えば，高齢者では膝関 節痛や腰痛等さまざまな障害を持つ場合が多 く, 整形外科で漫然とNSAIDsを長期投与されて いることがよくある. NSAIDsは腎血流を低下さ せるため, 高血圧や動脈硬化が進行している高 齢者では腎障害が進行する危険性が高くな る ${ }^{4)}$.また, 腎虚血を助長する利尿薬, RAS阻害 薬, カルシニューリン阻害薬等の併用でも
NSAIDsの腎障害を悪化させる. そのような場合 は，血清Cr值の定期的な測定を医師に依頼し， 医師にはNSAIDsの頓服での使用やアセトアミ ノフェンへの変更を考慮いただきたい。また， 重篤な腎障害患者には, シスプラチン（ラン ダ®)，アミノグリコシド系抗菌薬等の腎毒性の 強い薬物の投与を避け, できるだけ他剤を選択 すべきである.

\section{5. 何がハイリスク薬か}

米国では, 年間推定 10 万人の高齢者が薬剤有 害反応のために入院し, 緊急入院の原因のほと んどが2つの薬効で占められることが報告され ている ${ }^{5)}$. 1つは抗凝固薬・抗血小板薬による出 血, もう1つはインスリン・血糖降下薬による 低血糖である (図2)。これら4種の薬剤が薬剤 関連の緊急入院の 3 分の 2 を占め, これまでに 「ハイリスク薬」と指定された薬剤は入院原因 のわずか $1.2 \%$ しに関わっていないことが報 告された. そして, 入院のほぼ半数を 80 歳以上 の高齢者が占め, そのほぼ 3 分の 2 が意図的で ない過剩服薬によるものである.

具体的には, 抗凝固薬のワルファリンが緊急 入院の $33 \%$ に, インスリンが $14 \%$ に, アスピ リン及びクロピドグレル（プラビックス ${ }^{\circledR} ）$ 等 の抗血小板薬が $13 \%$ に, 経口血糖降下薬が $11 \%$ に関与している.もちろん, 抗がん薬は超ハイ リスク薬であるという点では, 医療従事者の意 識は高いと思われるが, 症例数が多く, 高齢者 に投与されることが多いため, 抗がん薬等につ いても, 投与後の注意深いモニタリングが必要 である。

ワルファリンは, 透析患者を含む末期腎不全 患者で出血リスクが 10.3 倍と有意に上昇し6), 腎機能低下患者に腎排泄性抗凝固薬のダビガト ランが投与されたことによって多くの出血によ る死亡者が出た. スルホニル尿素 (sulfonylurea：SU）薬は重篤な腎障害には禁忌となって 


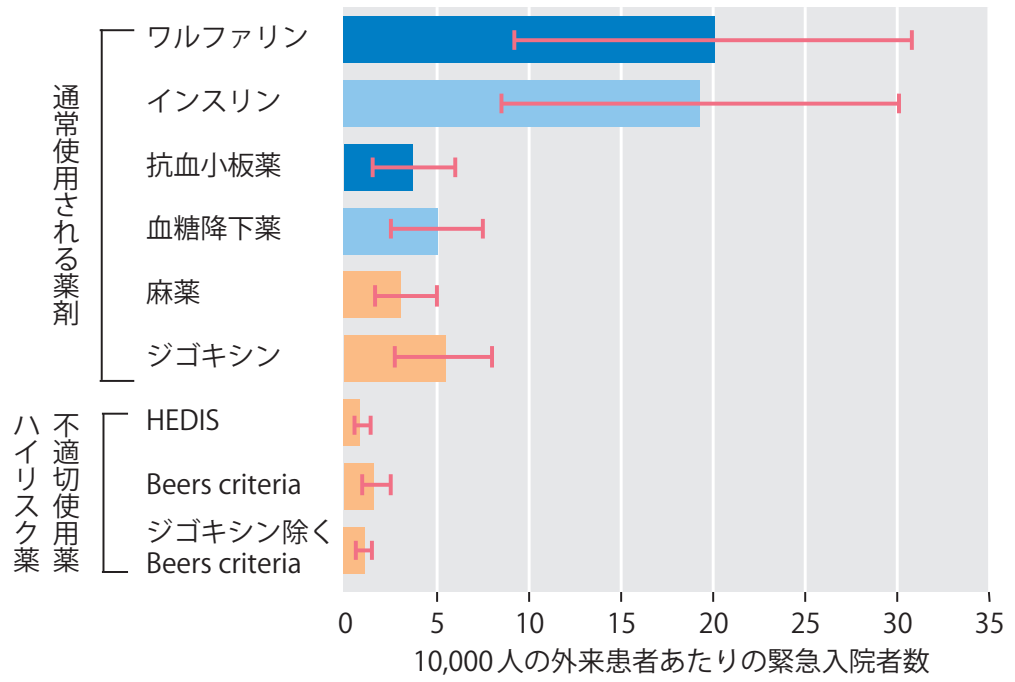

図 2 緊急入院の $2 / 3$ を抗血栓薬，糖尿病薬が占める

(Budnitz DS, et al : N Engl J Med 365 : 2002-2012, 2011 より改変)

いるが，HbA1cが非常に高值の症例には投与せ ざるを得ない場合があるかもしれない。ただ し，グリベンクラミド（オイグルコン ${ }^{\circledR}$, ダオ

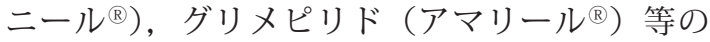
代謝物に活性のあるSU薬は, 活性代謝物が尿中 排泄されやすく，腎不全患者では蓄積して重篤 な低血糖を起こしやすいため，使用すべきでな い. 同様に，ナテグリニド（スターシス ${ }^{\circledR}$, ファ スティック $\left.{ }^{\circledR}\right)$ も，活性代謝物の蓄積によって 重症低血糖が起こったことから,「透析を必要と するような重篤な腎機能障害のある患者」には 投与禁忌となった。 また，SU薬の投与によって 分泌が充進したインスリンの $33 \%$ が腎で代謝 されるが，腎機能が低下すると，インスリンの 腎における代謝が遅延することによって低血糖 が遷延しやすく，同様に，腎機能低下患者では 低血糖を起こしやすい。 しかも，SU薬による重 篤な低血糖は心血管死亡リスクを上昇させるこ とが報告されている7).

ただし，これらの副作用を恐れるあまりに， これらの治療薬が適正に使用されないことにな ると, 前者では血栓症, そして, 後者では高血
糖によって，心血管病変の危険性が高まる。こ れらの薬は必要性が高いものの, 有効治療域の 狭いハイリスク薬であるため, 有効かつ安全な 投与設計を行う必要がある.

腎機能正常者に投与されても有害反応が起こ らない薬物であっても, 腎機能が低下すると八 イリスク薬に変わる薬物がある。 RAS阻害薬服 用者にスピロノラクトン（アルダクトン ${ }^{\circledR} \mathrm{A} ） や$ ST合剂（バクタ ${ }^{\circledR}$ ) を併用すると, 高カリウム 血症による突然死を招く可能性が高くなる。ま た, ワルファリンによる大出血発生率は, 未期 腎不全患者では高くなるため，透析患者の PT-INR (prothrombin time-international normalized ratio）は2.0未満に維持することがガイド ラインで推奨されている。重症心不全患者を対 象としたRALES (Randomized Aldactone Evaluation Study）試験において, 既存の心不全治療薬 に抗アルドステロン薬のスピロノラクトンを追 加し, 死亡率を $30 \%$ 減少できることが明らかに なった。 RAS阻害薬とスピロノラクトンの併用 はRALES study後に増加するとともに, スピロノ ラクトンによる高カリウム血症による死亡者数 
は 6.7 倍になったことが報告されている8 ${ }^{8}$.ま た，スピロノラクトンとST合剤併用により，他 の抗菌薬併用者の 12.4 倍（7.1２1.6倍）, 高力 リウム血症による入院リスクが上昇するという 報告がある ${ }^{9)}$.このように, 高力リウム血症は, 腎機能低下時に発現する可能性が高くなる致命 的な副作用の 1 つであり, 外来においては, 高 齢者で心不全患者の場合は特に, 検査を十分に 行う必要があるものと考えられる．このため, 致命的な副作用を来たす恐れのあるハイリスク 薬による有害反応を防ぐことも医師・薬凨師の 重要な役割と思われる.

前述のように, 2011年には新規抗凝固薬であ るダビガトラン (プラザキサ $\left.{ }^{\circledR}\right)$ 服用患者で出 血性副作用による死亡例が, 発売半年で 24 例報 告された. 多くは, CCrが $30 \mathrm{ml} /$ 分未満の投与 禁忌の高齢者であった ${ }^{10)}$. ダビガトランは尿中 排泄率が $85 \%$ と高い腎排泄性薬物であり, P-糖 タンパク質の基質薬物であるため, 心房細動で レートコントロールに併用されるベラパミル (ワソラン ${ }^{\circledR}$ ) によって血中濃度が上昇し, 出血 リスクが高まる相互作用に配慮する必要があ る. 実際にベラパミルが投与されているにもか かわらず，ダビガトラン $300 \mathrm{mg} /$ 日・5日間投 与で脳出血を起こし, 意識回復を認めていない 80 歳代男性の報告もある.

他の直接経口抗凝固薬 (direct oral anti-coag-
ulants：DOAC）は腎排泄性薬物ではないとはい え，いずれも代謝酵素のCYP3A4の基質であり， 薬物排泄トランスポータのP-糖タンパク質の 基質でもあるため，イトラコナゾール（イトリ ゾール $\left.{ }^{\circledR}\right)$ 等の阻害薬による出血リスク増大は もちろん, リファンピシン (リファジン $\left.{ }^{\circledR}\right)$ 等 の代謝酵素誘導薬による血栓症リスク増大等の 相互作用にも厳重な注意が必要である。これら の点については, 薬物動態・相互作用を専門と する薬剤師との連携及び薬剤師による処方監査 が非常に重要である.

\section{まとめ}

薬劑師は薬物動態や相互作用の知識に長けて おり，医師の異なった視点から処方を見て,よ り有効かつ安全で, 目の前の患者さんに配慮し た最高の薬物療法を責任もって提供できるよう にする役割を担っていると考える. 2018年には 看護師, 管理栄養士とともに薬剤師も腎臓病療 養指導師に認定されることから, 今後, 慢性腎 臓病の薬剤管理を多職種連携を充実させるため のリーダーシップを医師とともに担っていく必 要性がある。

著者のCOI (conflicts of interest) 開示: 本論文発表内容 に関連して特に申告なし 
1) Lilja JJ, et al : Grapefruit juice-simvastatin interaction : effect on serum concentrations of simvastatin, simvastatin acid, and HMG-CoA reductase inhibitors. Clin Pharmacol Ther 64 : 477-483, 1998.

2）平田純生, 門脇大介：緊急提言：CKDを腎不全に進行させない薬物療法 腎毒性薬物の投与忌避. 薬局 $58: 3010-$ $3121,2007$.

3）平田純生，他：患者腎機能の正確な評価の理論と実践. 日腎薬誌 $5: 3-18,2016$.

4）平田純生，他：NSAIDsによる腎障害：COX-2 阻害薬抢よびアセトアミノフェンは腎障害を起こすか。日腎誌 58 ： 1059-1063, 2016.

5) Budnitz DS, et al : Emergency hospitalizations for adverse drug events in older Americans. N Engl J Med 365 : 2002-2012, 2011.

6) Jun $\mathrm{M}$, et al : The association between kidney function and major bleeding in older adults with atrial fibrillation starting warfarin treatment : population based observational study. BMJ $350:$ h246, 2015.

7) Schejter YD, et al : Characteristics of patients with sulphonurea-induced hypoglycemia. J Am Med Dir Assoc 13 : 234-238, 2012.

8) Juurlink DN, et al : Rates of hyperkalemia after publication of the Randomized Aldactone Evaluation Study. N Engl J Med 351:543-551, 2004.

9) Antoniou $\mathrm{T}$, et al : Trimethoprim-sulfamethoxazole induced hyperkalaemia in elderly patients receiving spironolactone : nested case-control study. BMJ 343 : d5228, 2011. doi : 10.1136/bmj.d5228.

10）高橋尚彦：市販後調查に学ぶ。心臓 $47: 130-134,2015$. 